\title{
Tapestry (Goblen) Dokumaları
}

Ömer ZAIMOĞLU*

\section{Tapestry (Goblen) Weavings}

\section{ÖZET}

Resimlere konu olmuş kompozisyonların özellikle dokuma sanatında tercih edilmesi tapestry denilen dokuma türünün doğmasını sağlamıştır. İnsanlık tarihi kadar eski olan dokuma sanatında resmin kullanılması milattan öncelere dayanmaktadır. Doğu kökenli bu dokuma türünün gelişimi ortaçağ Avrupa'sında başlamış, özellikle XVII. yy. Avrupa'sında kralların, soyluların, zenginlerin saraylarında gösterişin bir simgesi haline dönüşmüştür. Bu çalışmada tapestry sanatının tarihi gelişim süreci anlatılırken, dokuma tekniği üzerinde ayrıca durulmuştur

Anahtar Kelimeler: Goblen, Düz Dokuma, Resim, Yün, Boya, Sanat Tarihi

\section{Giriş}

Resim Sanatına konu olmuş kompozisyonların birçoğu dokuma sanatında sıklıkla görülmektedir. Bununla beraber bu etkilenme aynı oranda tekstil sanatına da yansımıştır. Genel anlamda "goblen" resimli duvar dokumalarına verilen addır.

İngilizce ve Fransızca'da (ing. Gobelin, Fr. Gobelline) anlamına gelen gobelin günümüzde duvar halısını tanımlayan "tapestry" ile de eş anlama gelmektedir. Tapestry sözcüğü Grekçe tapi Latince tapesium'dan gelen ve çeşitli teknikleri içeren bir anlamı ifade eder. ${ }^{1}$

\footnotetext{
Yrd. Doç. Dr. Akdeniz Üniversitesi, Güzel Sanatlar Fakültesi, Geleneksel Türk El Sanatları Bölümü Öğretim Üyesi, Antalya, e-posta: omerzaimoglu@gmail.com

Assist. Prof. Dr., Akdeniz University, Faculty of Fine Arts, Department of Traditional Thrkish Handicrafts.

1 A. Sürür, "Duvar Halıcılığı", Tirkityemiz, Ekim 1981, Sayı 35, s. 21.
}

\section{ABSTRACT}

When the compositions, which have been the subjects of paintings, started to be used in the art of weavings, the weaving type called "tapestry" emerged. The birth of the art of weaving, which is as old as the history of mankind, dates back to the periods before Christ. The development of this east- originated weaving type started in Middle Age Europe and it became a symbol of prestige for the palaces of the noble, especially during the XVII ${ }^{\text {th }}$ century. This study explores the developmental lineage of the tapestry and analyzes the weaving technique.

Keywords: Goblen, flat weaving, imagery, wool, dye, art history, tapestry.

Goblen resimli duvar halısı ilk kez 1603'te Fransa'da Gobelin ailesinin atölyesinde dokunmuş, daha sonra buradan Avrupa'ya yayılmıştır. ${ }^{2}$

Daha çok figüratif desenli, atkı yüzlü goblen dokumaları duvar halısı olarak dünyanın pek çok yerinde eski zamanlardan beri üretilen bir dokuma türüdür. ${ }^{3}$

1662-63 yıllarında Fransa kralı XIV. Louis'in ( 16381715) Maliye Bakanı Jean-Baptiste Colbert (16191683) Paris'teki atölyeleri Gobelin'ler ailesine ait malikânenin çatısı altında bir araya getirterek bu süreçten sonra dokuma faaliyetlerinin tek noktadan yürütülmesini sağlamıştır. Daha sonra Paris'in diğer iyi zanaatçıları da bu birliğe dâhil olmuşlardır. Genel başkanlığını Charles Le Brun'un (1619-1690) yaptığı Gobelin imalathanelerinin ürünleri XIV. Louis'in sarayının süslenmesinde kullanılıyordu. Bu devirden itiba-

A. Ergür, Tekstil Terimleri Sözlüăü, İstanbul, 2002, s.93

3 A. Ergür, age, s. 259. 
ren bu imalathanelerde üretilen Tapestry dokumalar "Gobelin" (Goblen) ismiyle adlandırılmaya başlandı. ${ }^{4}$

Gobelin ismi Fransız Goblen ailesi tarafından dokunduğu için verilmiş bir ad tır. Daha sonrası aynı kelime için Resimli Dokuma anlamına gelen Tapestry şeklinde söylenir hale gelmiştir. Resimli dokumalar için Tapestry terimini kullanmak daha az kavram karmaşası yaratacaktır. ${ }^{5}$

Kültür tarihinin bir parçası sayılan dokuma sanatı içinde önemli yere sahip resimli ürünler tarihi ilk çağlara dayanmaktadır. Tapestry sanatı, tekniği, malzemesi, tasarımı ile özgün el dokumacılığı içerisinde önemli yer tutar. Büyük emek ve zaman isteyen bu sanat, elle dokunmaktadır ve hiç bir zaman fabrikasyon hale gelmemiştir. ${ }^{6}$

Dokuma alanında duvar halıları üretimin maliyetli ve dokumanın zahmetli oluşu duvar halılarına sahip olma ayrıcalığını da yalnızca varlıklı kimseler ve kraliyet ailesine vermekteydi. Dolayısıyla bugün duvar halıcılığının birçok alanda araştırma konusu olması bu anlamda şaşırtıcı değildir. ${ }^{7}$

\section{Tapestry Dokuma Tekniği}

Özgün el dokumacılığı içerisinde yer alan Tapestry, tarih öncesi dönemlerden itibaren kilimlerde de görülen dokuma tekniklerindendir. Üst üste atılan atkı ipliklerinin çözgü yüzeyini kapatmasıyla oluşan doku, tapestryi meydana getirir. ${ }^{8}$ Tapestry sanatı devamlı atkı ipliklerinden oluşan bir düz dokuma tekniğidir. Karakter ve yapıları eşit olmayan iki grup atkı ve çözgü iplikleri beraber kullanılır. Doku gelişirken el aletleriyle sıkıştırılan üst üste enine atılan atkılar çözgüyü kapatarak doku yüzeyine egemen olur. Yüzeyde çözgü iplikleri görünmez ancak dokumanın arkasındaki birleşim yerlerinde bu durumu görmek mümkündür. ${ }^{\circ}$

Klasik tapestry dokumalarında boya, çok dikkatli incelemelerden geçirilmiş, ışığa dayanıklılığı tecrübe edilmiştir. Boyalar bazı bitkilerin kullanımıyla elde edilmiştir. Boyama yöntemleri, Tapestry için oluşturulan esnaf birliği teşkilatının denetlediği önemli bir iş olmuştur. ${ }^{10}$

Ortaçağda renk paletinin kısıtlılığı, doğanın taklidini önlerken, renk seçimleri konusunda zorunluluk ve yapaylığı beraberinde getirmiştir. Hachure tekniği kullanılarak tonlar karıştırılmış ve tasarımlarda üç boyut

4 V. Paşayeva.-Ü. Hamidova, "Goblen'de Kullanılan Teknik Yöntemler", Sanat, Sayl 3, 2003, s. 150.

5 S. Özay, Dünden Bugüne Dokuma Resim Sanat, Ankara 2001, s. 3.

6 F. Altın, Dokuma Resim (Tapestry) Sunatunda Çağdaş Etkiler, Atatürk Üniversitesi Sosyal Bilimler Enstitüsü Resim Anabilim Dalı Yayımlanmamış Yüksek Lisans Tezi, Erzurum 2010, s. 99.

7 S. Grant, Tekstile and Ant. Art and Culture Magazine, (Bahar 2007). Say1 44, s. 46

8 F. Altin, age., s. 1.

9 F. Altin, age., s. 99

10 F. Altin, age. s. 51

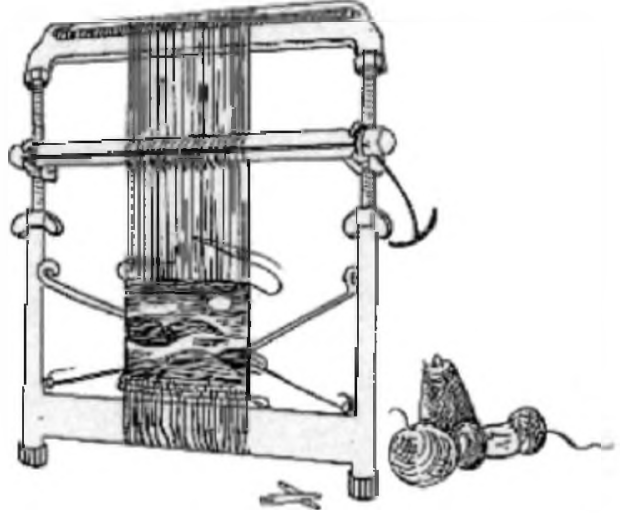

Çizim 1. Tapestry Tezgâhı

yaratmada yöntem olarak kullanılmıştır. Hachure tekniğinin ((i.), (f.), (güz. san.), resimde gölge çizgileri; haritalarda dă̆ yamaçann gösteren ince çizgi, tarama çizgi; (f.) tarama çizgilerle göstermek.) yaygın kullanımı Tapestry'in büyük ölçüde ilgi çekmesine neden olmuştur.

Dokumanın ana malzemesi yündür. Atkıların yünden oluştuğu tasarımlarda, yalnız figürlerin gözlerinin beyazında çok nadiren pamuk malzeme de tercih edilmektedir. " Tapestry'lerin yapımında prensipte aynı olan dikey ve yatay iki çeşit el dokuma tezgâhı kullanılmıştır. Yüksek atkılı tezgâh dikey (Çizim 1.) ve alçak atkılı tezgâh yatay olarak bilinir. Dikey veya yüksek atkılı tezgâh, en eski tezgâh tipidir. Temelde çözgülerin gerildiği çok ağır iki silindir prensibine bağlı büyük olasılıkla çözgüleri ağırlıklarla sağlanan, eski Mısır'daki tezgâhların devamıdır (Çizim 2-3). Bu tezgâh Anadolu'da kullanılan ve ismine el tezgâhı denilen tezgâhlarla aynıdır. ${ }^{12}$

Tapestry dokuyucusu dikey veya yüksek çözgülü tezgâhlarda, dokumayı tezgâhın arkasından, yani tersten çalışır (Çizim 4-5). Renklerin üzerine kodlandığı büyütülmüş desen karton, dokumanın önüne, duvara asılır. Dokuyucu, dokunun gelişimini ancak düzenli yerleştirilmiş aynalarda izleyebilir. ${ }^{13}$

Tapestry dokumalarında tasarım bakımından yaratıcılık ön planda olup kullanılan malzeme ve dokuma metotlarında hiçbir kısıtlama söz konusu değildir. Çizim ve renk dokuyla birleşerek en önemli unsuru, yaratıcılığı ortaya koyar. Tasarım sürecinde sanatçının resimsel anlayış ile şiirsel bütünlüğui ortaya koyabilmesi bu bakımından çok önemlidir. Sanatçı kendi bakış açısından yola çıkarak, belirli yollar izleyerek veya eskizlerden yararlanarak eserini meydana getirir. Malzeme ve metot sınırlaması olmaması yaratıcılığı geliştirir.

Tapestry ve kilim aynı tekniğin kullanılarak yapıldığı dokumalardır. Tapestryler Rönesans ve öncesinde önemli bir sanat türüyken bu devirden sonra ise canlılığını yitirir. Ancak şunu belirtmek gerekir ki; tapestryler ticari ve sanatsal bir meta haline gelmeyen, gelişip değişmek yerine gelenekselleşen Anadolu ki-

\footnotetext{
11 S. Özay, age., s.32.

12 İ. Fazlığlu, Eskiçağda Dokuma, İstanbul 1997, s. 12-13

13 S. Özay, age., S. 63
} 


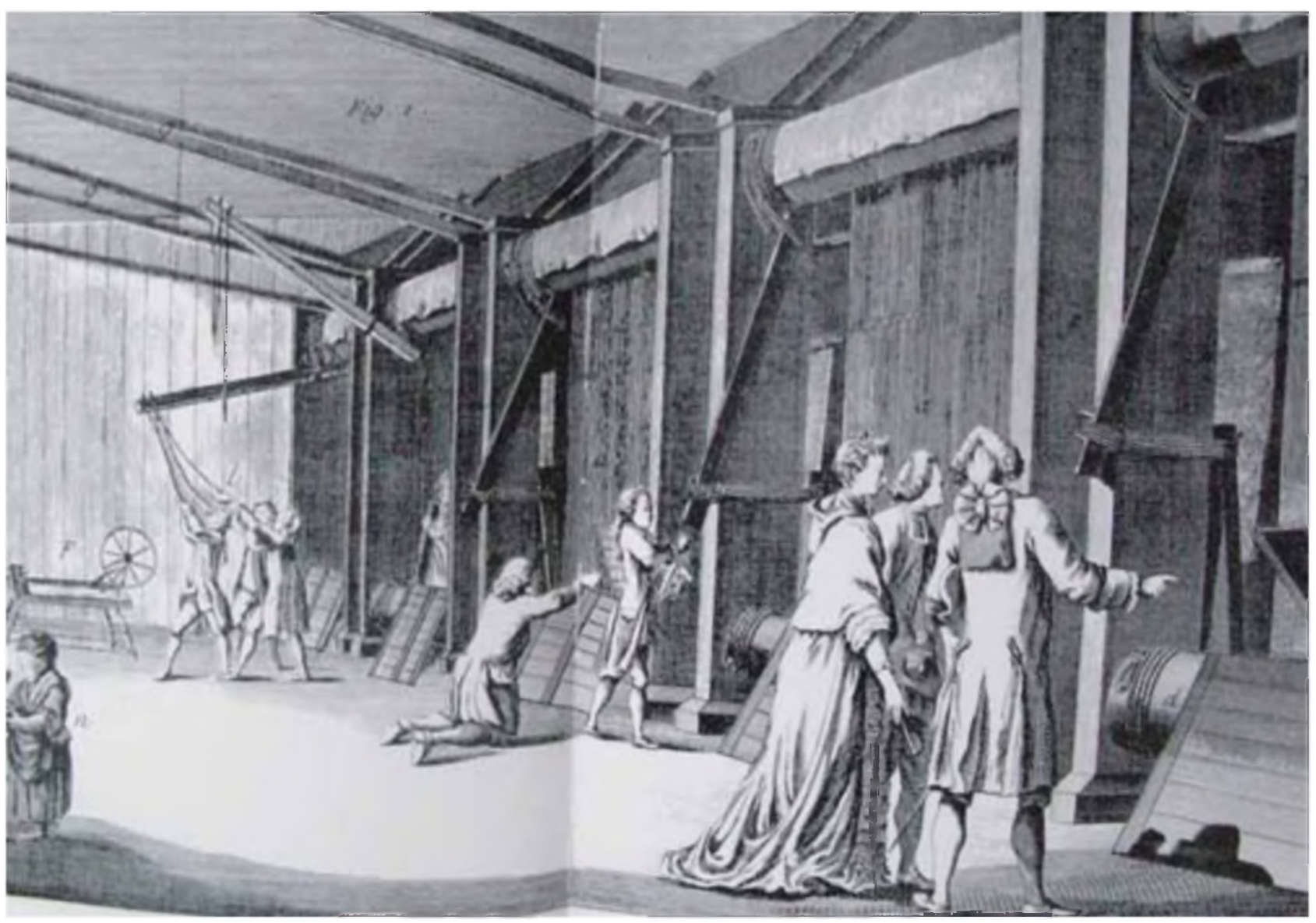

Çizim 2. Tapestry tezgâhı büyük dokumalar için(Ames De Lame Et De Sole.Jacqueline Boscara)

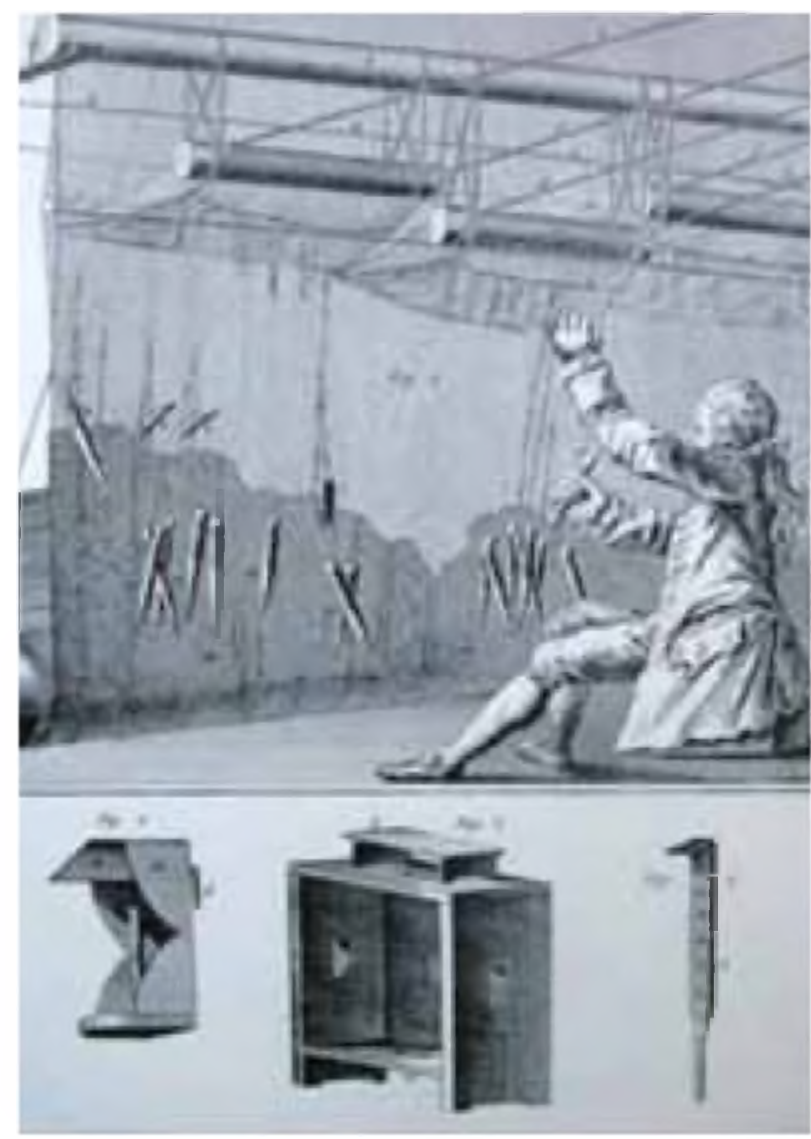

Çizim 3- 5. Tapestry tezgâhı(Ames De Lame Et De Sole.Jacqueline Boscara)

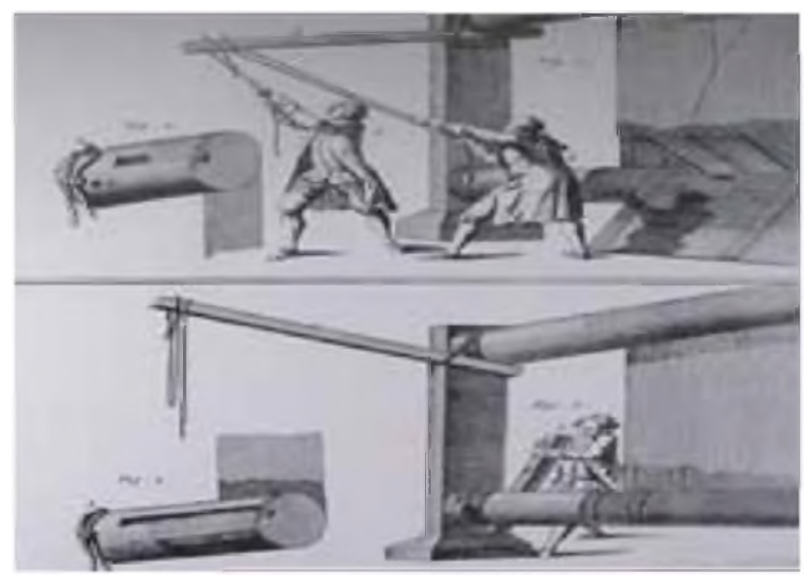

Çizim 4. Tapestry tezgâhı (Ames De Lame Et De Sore. Jacqueline Boscara)

limleriyle benzer birçok özelliğe sahiptir. ${ }^{14}$ Tapestrylerin kullanıma hazır hale gelinceye kadar geçirdiği aşamalarda dikkat edilmesi gereken önemli unsurlar şu şekilde sıralanabilir:

- Dokunacak desenin kalıbını çıkarmak

- Dokuma planını çıkarmak,

- Dokunacak resmin boyasına uygun boyalarl tespit etmek. ${ }^{15}$

14 S. Özay, age, s.62.

15 Ö. Zaimoğlu, "Kazak Goblen Sanatı", Yesevi, (Mart 2009), Sayı 183, s. $32-33$ 


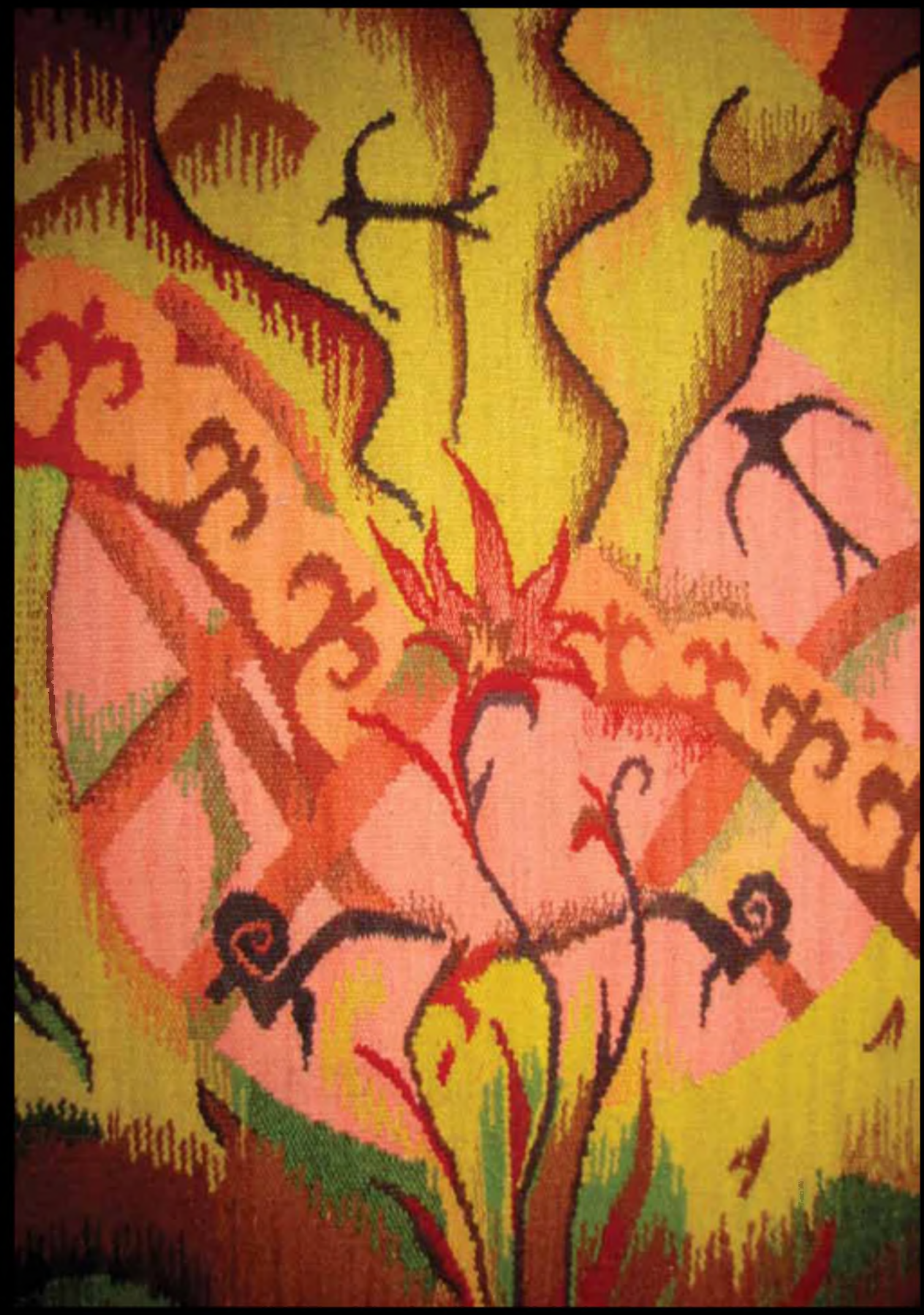


Tapestrylerde desen, canlı öğeler de içeren hikayeci bir anlatıma sahiptir. Tapestrylerin sembolik anlamda benzetmeci ifadelere sahip olması, motiflerinin yörelere göre farklılıklar göstermesi ve dokumalarındaki gerçekçi hikaye anlatımları ile kilimlerden ayrılır. Tapestryler önceden hazırlanan desen patronlarına göre genellikle ressamlar tarafından çizilen desenlere dayanarak dokunmuştur. Bu nedenle dokumanın ortaya çıkış sürecinde dokuma desenini çizen ve desene bağlı dokumayı yapan farklı kişilerdir. Dokuyanlar resmi taklit ederek dokumanın çok daha ötesine geçerek gölgeleme, illuizyon, perspektif ve mekan kaygısına girmişlerdir. Tapestrylerde motifler ve desenler dönemden döneme farklılıklar göstermiş desenler Anadolu kilimlerindeki gibi gelenekselleşmemiştir. ${ }^{16}$

\section{Tapestry'nin Tarihi Gelişim Süreci}

Günümüze ulaşan ve bilinen en eski Tapestry- Kopt kumaşlarıdır. Kopt dokumacıları tapestry dokuma tekniğini geliştirmiş halen kullanılan yöntemleri keşfetmişlerdir. Tapestry dokuma sanatı çok uzun bir ta-

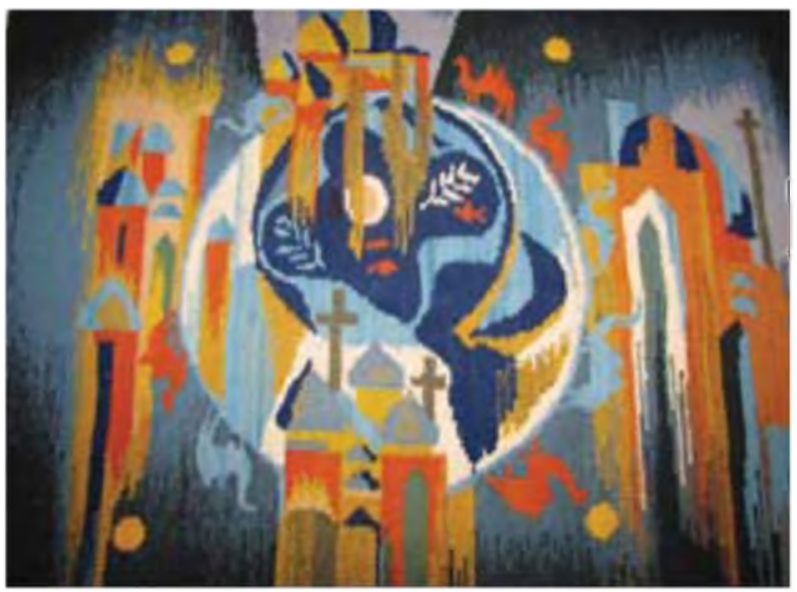

Foto 10. Tapestry örneği (Türkistan Kubbeleri 80x100 Ömer Zaimoğlu)

rihe sahiptir. Illk tapestry ne zaman ve nerede yapıldı bilinmemekle beraber bu dokuma prensibi Eski Mısıra kadar dayandığı söylenilmektedir. ${ }^{17} \mathrm{M} ı$ sırda, Kahire müzesinde sergilenen keten örtüye lotus, palmet, ve skarabe (Skarabe, Eski Mısır'daki en yaygın sembollerden biridir. Mısır tradisyonunda farklı bağlamlarda, üç değişik anlamda kullanılmış olan semboldür.) tasvir edilen nakışlar dokunmuştur. Bu örtü IV. Tutmos türbesinde bulunmuştur ve (M.Ö.) 1400 yilına tarihlendirilmektedir. Asya'da ise bu sanat dalında Çinli ustalar çalışmıştır. Oysa 1949-50 yıllarında Altay Dağlarının Pazırık ve Başadur Vadi'lerinde yapılan kazılarda, Hun Kurganları'nda ele geçen ve M.Ö. V. III. yüzyıllara ait olduğu tespit edilen kilimde insan figürleri tasvir edilmiştir. Mısır'da bulun-

\footnotetext{
16 N. Önlü, S. T. Arabalı Koşar, "Tapestry Dokumalarının Geleneksel Anadolu Kilimleri İle Karşıllaştırılması", 10. Ulusal El Sanatlan Sempozyumu, İzmir 2009, s. 302-303.

17 http://www art-gobelen.ru/history.php
}

muş Hıristiyanlık dönemine ait çok sayıda Kopt dokumalarında çeşitli hayvan ve insan figürleri, mitolojik konular içeren karmaşık kompozisyonlar yer almaktadır. ${ }^{18}$ Bu dokumalar XIII.-XIV. yüzyıllarda Batı Avrupa'da gelişmeye başlayan tapestry dokumacılığının tarihini çok daha eski devirlere taşımakta ve aynı zamanda Türklerin daha milattan önce bu dokuma tekniğini bildiklerini kanıtlamaktadır.

Batı Avrupa'da bulunmuş ilk tapestry dokumalarının XI-XII. yüzyıllara ait olduğu tahmin edilmekte ve bu sanatın gelişmeye başlaması ise XIV. yüzyıla tarihlendirilmektedir. 1300'lü yıllara ait arşiv kayıtlarında Paris ve Arras'da basit amblem ve dekoratif motifli tapestryler dokunduğu bilinmektedir. Yalnız H. 1350 yılından sonraki devirde bu dokumalarda çeşitli resimler tasvir edilmeye başlanmıştır. Tapestry dokuma sanatı Batı Avrupa'ya Müslümanlar, Doğudan İspanya aracılığıyla geçmiştir. Avrupa'da ilk tapestryler (goblenler) fresklerde olduğu gibi ilk önce kilisenin siparişi üzerine dokunmuştur. Bu örneklerde genelde tarihi veya dini olaylar tasvir edilmiştir. XIV. yy sonunda tapestry ev süslemelerinde önemli bir unsur olmuştur (Foto 9-10). Binaların ısı yalıtımı için duvarlara, pencere ve kapı açıklıklarına ve odaları bölme amaçlı eleman olarak kullanılmıştır. ${ }^{19}$

XIV. yüzyılda Fransiz tapestryleri ve Arras dokumaları dikey tezgâhlarda dokunmaya başlayınca, tapestrylerin kalitesi en yüksek seviyelere ulaşmıştır. Bu tarihten sonra tapestry krallar ve soylular arasında dokutulan bir sanat yapıtı olmaya başlamıştır. Teknolojik gelişmeler ve sanatsal olanaklar bu dokuma türünü bir sanat kolu olmaktan öteye taşımış, bir sanat eseri niteliğine ulaştırmıştır.

XVI. yüzyıldan sonra Gotik tapestry'lerde uygulanan teknikler geliştirilerek, özellikle biçimler iki boyutluluktan çıkıp üç boyutlu görünüme ulaşmıştır. $\mathrm{Bu}$ dönemde en önemli gelişme sayılan Perspektif tapestry sanatına da girmiştir. Çok iyi taklit edilerek dokunan Raffaello' nın seri halinde dokunan "Havarilerin İnişi" adlı eseri buna en iyi örnektir. ${ }^{20}$

$X V$. yüzyll itibari ile Fransa, İtalya, İspanya ve Almanya'da gelişim gösteren bu sanat daha sonra Baltık ülkeleri, Kafkasya ve Rusya'ya da yayılarak ilgi odağı olmuştur. Bu ülkelerde kendine has dokuma malzemelerinin varlığı goblen sanatına yeni bir bakış açısı getirmiştir. Baltık, Kafkasya ve Rusya ülkelerinde dokuma amaçlı kullanılan kendir, kamış ve yün eğirmesi ipler goblen sanatında da kullanılmıştır. Baltık ülkelerinde goblen dokumada genellikle doğa resimleri, Kafkas ülkelerinin goblenlerinde kendi tarihlerinden ve destanlarından önemli kesitleri anlatan resimler, Rusya'da ise kilim örnekleri kullanıla-

\footnotetext{
18 http://www art-gobelen .ru/history php

19 B. Vipper, Videnie istoriçeskoe izucenie iskustva (Rusça), Moskova, 2004.

20 A. Sürüı, "Goblen Dokumacılı̆̆ı”, Thikiłemiz, (Şubat 1982), Savı 36, s. 17
} 
rak değişik resimler dokunmuştur. Goblen dokuma da çağlar boyunca çeşitli resimlerin kompozisyonlara konu olduğu görülmektedir.

Dokuma resim Rönesans'a kadar hazır desenlerin kullanılmasıyla gelişimini sürdürmüştür. 19.yy’a kadar gelişim gösteren bu sanat daha sonraları üretimde düşüş göstermeye başlamıştır. ${ }^{21}$ William Morris ve bazı arkadaşlarının başlattığı Arts \& Crafts (Sanat ve Zanaat) hareketi tapestry sanatını canlandırmıştır. ${ }^{22}$

$X X$. yüzyılın ortalarına doğru Fransız ressam Iean Lurcat eserleriyle yeni bir tarzla ortaya çıkarak tapestrylerde resim tasvirinden vazgeçerek basit ve yalın biçimlere, soyut ve dekoratif motiflere, renk ilişkilerine yönelir. Böylece tapestry bugünkü görünümüne ulaşır. Lurçat'ın eserleri Aubusson'da Madam Cuttoli'nin idaresinde çalışan dokumacılar tarafından dokunurken Lurçat ise Cuttoli okulunda renk dersleri veriyordu. Bu adımla tekstilci ressamlar yetişmesi sağlanırken goblen herkesin kabul ettiği bir sanat alanına dönüşür. ${ }^{23}$

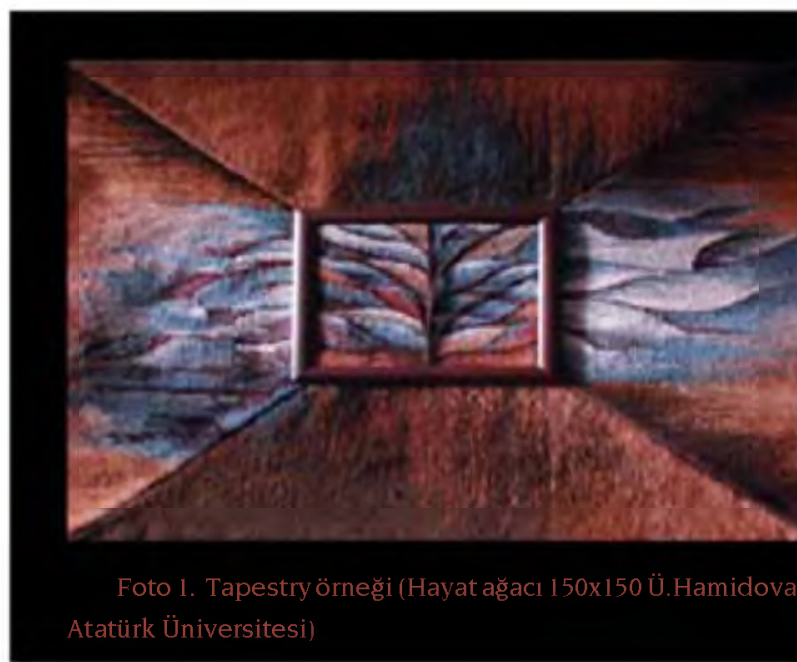

Yine son yıllarda tapestrynin gelişiminde ünlü Fransız ressam ve dekoratif sanatının ustası Jan Lürs'ün katkısı büyüktür. Jan Lürse ve goblen dokuma ustası F. Tabar goblenin kompozisyonunu, kullanılan malzemeleri ve dokuma tekniğini değiştirmemiş fakat goblen dokumada kullanılan renk çeşitliliğine sınırlamalar getirmiştir. Lürs'ten sonra goblen sanatına emeği geçen en önemli ressamlar: Homer, Pikar ve Ledu'dur. 1946'da Matiss, Bove fabrikası için "Polinezi" (Paris, Mobilye National) eskiz kartonu hazırlarken bunu takiben Goblen sanatında 1960 yıllarında kullanılmaya başlayan kabartma tekniği ile hızlı gelişim sürecini görmekteyiz. Goblen ustaları önceden daha önceki kullanılan teknikleri, renk uyumunu, kullanım alanlarını inceleyerek yeni teknikler geliştirmeye çalışırlar. Goblen dokuma da en önde ge-

21 http://www alfadekor ru/index php?Eact=61

22 C. London, Tapestries, Milan, 1988, s.131.

23 V. Paşayeva, - Ü. Hamidova, "Goblen'de Kullanılan Teknik Yöntemler", Sanat, Say1 3. 2003 s. 150.

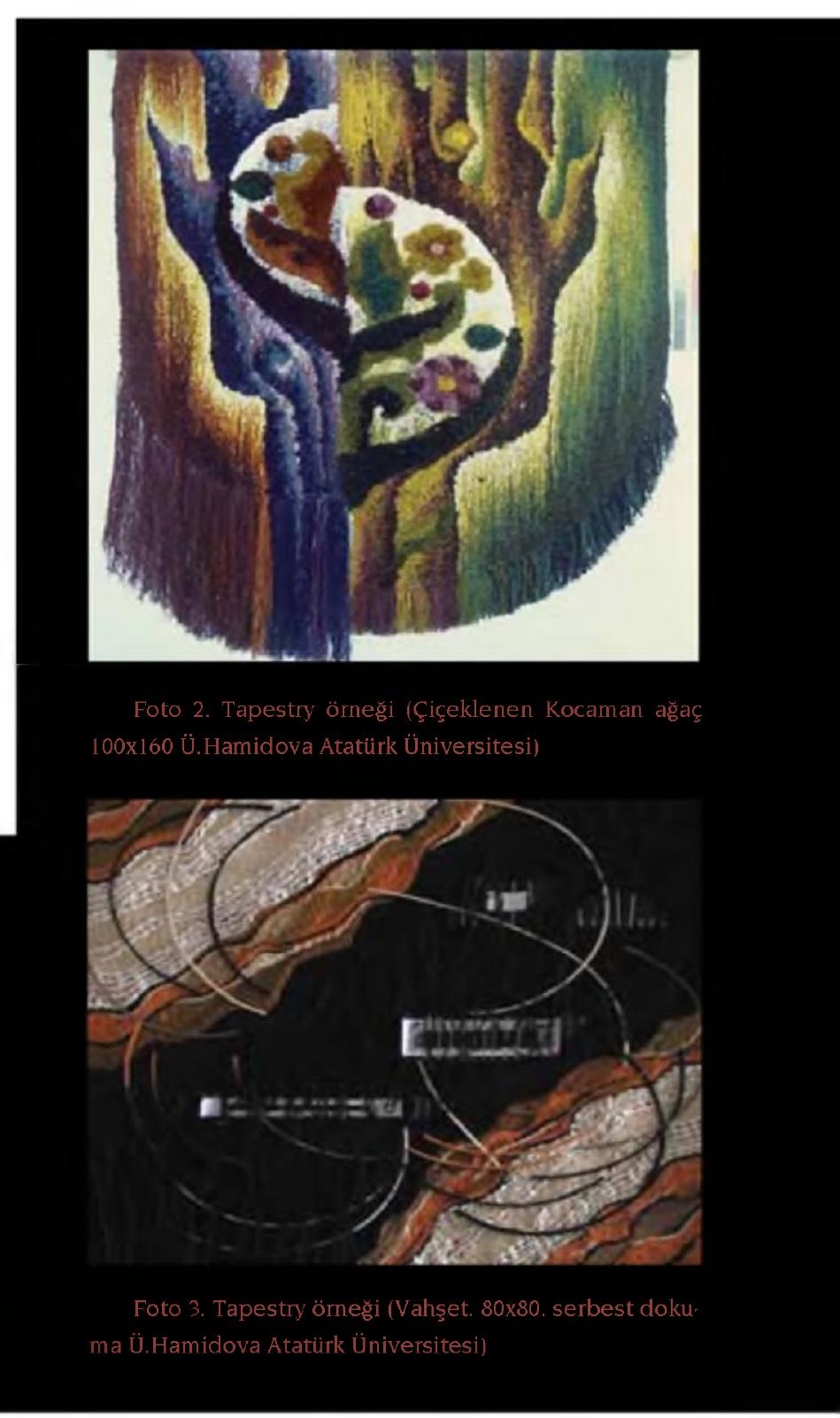

len faktörlerden biri olan çeşitli renklerde ki ipleri tercih etmeye başlarlar. Bununla birlikte kullanılan resmi detayları ile inceleyerek renk uyumuna ve ortaya çıkardıkları eserlerin tüm ayrıntıları ile görünmesine dikkat etmişlerdir (Foto 1-2-3). Bu goblenin sanatsal alanda gelişimine de tesir etmiştir. ${ }^{24}$

Günümüzde tapestry sadece bir resim görünüşünde olmayıp, üçboyutlu konstrüksiyonu ve rölyefli dokusuyla estetik bir etki yaratmaktadır. Günümüzde goblen (tapestry) geleneksel sanatın önemli değişimlere uğradığı, tabii sanattan anıtsal sanata doğru büyük adımların atıldığı bir alandır. ${ }^{25}$

\section{Sonuç}

Bir dokuma türü olan tapestry tarihini incelediğimizde ilk buluntularının M.Ö. III. yüzyıla kadar indiğgi söy-

24 K. Bolatbaev., kökiliek iane kenistik (Kazakça), Almatı, 2008, s. 117.

25 V. Paşayeva, Ü. Hamidova, age., s. 150. 
lenilebilir. Altay Dağları'nda yapılan kazılarda Hun Kurganlarında bulunan kilimde insan figürleri resimli dokumaların ilk örneklerinin tespiti Türklerin binlerce yıl önce bu sanatı icra ettiklerini göstermektedir. Tarihi Eski Mısır'a dayandırılan dikey ve yatay tezgâhlarda dokunan atkı yüzlü dokuma türü olan en eski tapestry
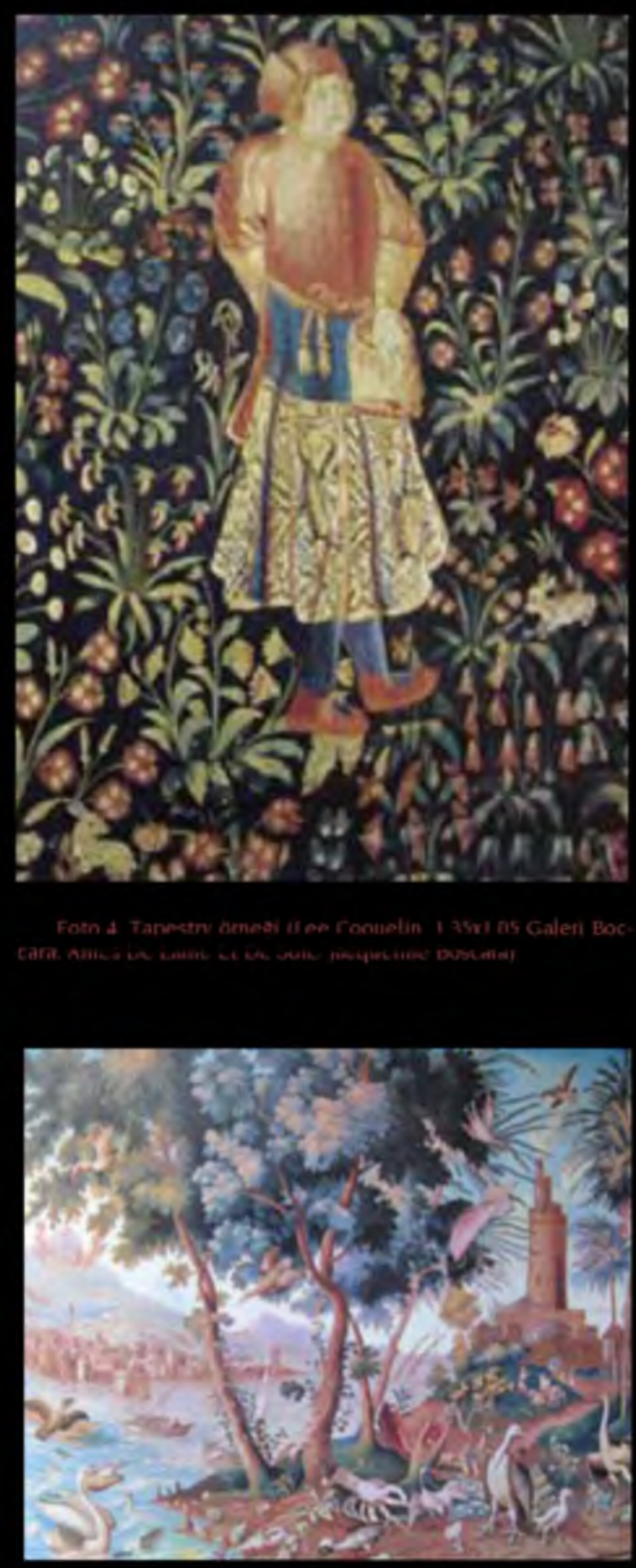

örnekleri Kopt kumaşlarında karşımıza çıkmaktadır.

Tapestry Avrupa dokuma sanatında XI. yüzyılda başlamış ve en büyük gelişimini burada yaşamıştır. İlk zamanlarda kilise tarafından sipariş edilen tapestrylerde dini olaylar tasvir edilirken daha sonralarl Avrupa'da büyük gelişim göstererek adeta gösterişin sembolü haline dönüşmüştür. XVII. yüzyılda Avrupa saraylarında sarayın içinin de dışı gibi görkemli olmasına özen gösterilmesinden resimlerin dokunarak duvarları süslemesi giderek daha önemli bir hal almaya başlar. Bu dönemde Gobelin ailesinin sahip olduğu köşkte kurulan imalathanede saray için resimli dokumalar yapıldığından Tapestry (resimli düz dokuma) Goblen adını buradan alır ve bu sanata "Kraliyet Sanatı Goblen" denmesi ise buna bağlıdır.

Tapestry belli bir yörenin veya kültürün ürünü olmayıp dokuma kültürünün yaygın olduğu her yerde uygulanmıştır diyebiliriz. Gelişiminde en parlak dönemi Avrupa'da gerçekleştirmiş olup günümüz kaynaklarına göre doğu kökenlidir fakat doğuya ait kalmamıştır. Dokunduğu her bölgede oranın kültüründen izler taşımaktadır (Foto 4-5-6). Örneğin Türkiye'de tapestrylere Anadolu kilimleri örnek gösterilir. Anadolu kilimleri dokuma tekniği ve görünüm olarak tapestrylerle büyük benzerlikler göstermekle beraber Anadolu kilimlerinde kullanılan motifler Anadolu kültürünü ve yaşam tarzlarını yansıtmaktadır.

Tapestry dokunduğu döneme ait izleri taşır Tezgâhın arkasına yerleştirilen desen kartonu dikkate alınarak dokunduğu için konu çeşitliliğinde hiçbir sınırlaması yoktur. Tapestryler dokunduğu dönemin tarihi, kültürel, sosyo-ekonomik, yaşam tarzı gibi birçok unsuru içinde barındırır. Özellikle Avrupa'da dokunan tapestryler dokunduğu dönemin resim anlayışı hakkında önemli bilgileri yansıtır. Örneğin XVI.

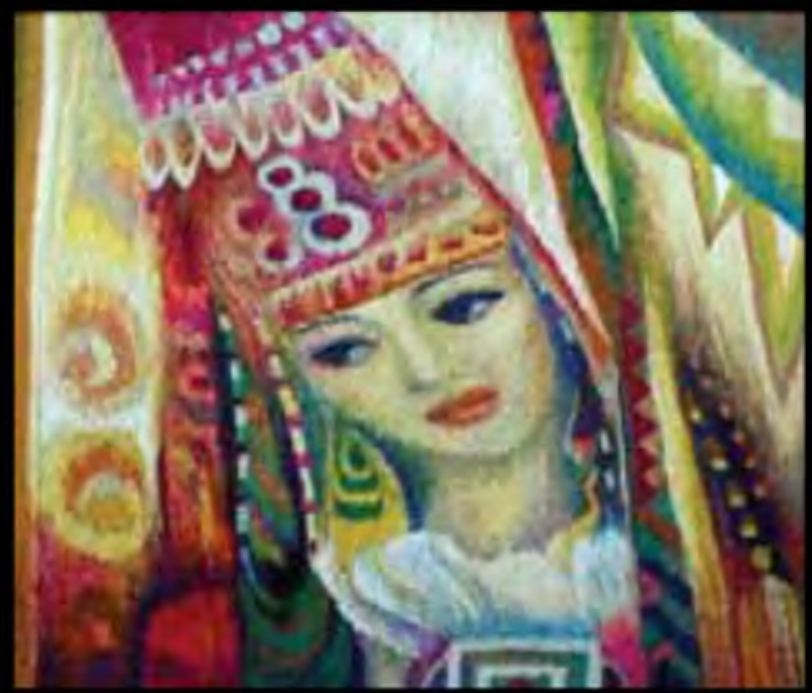




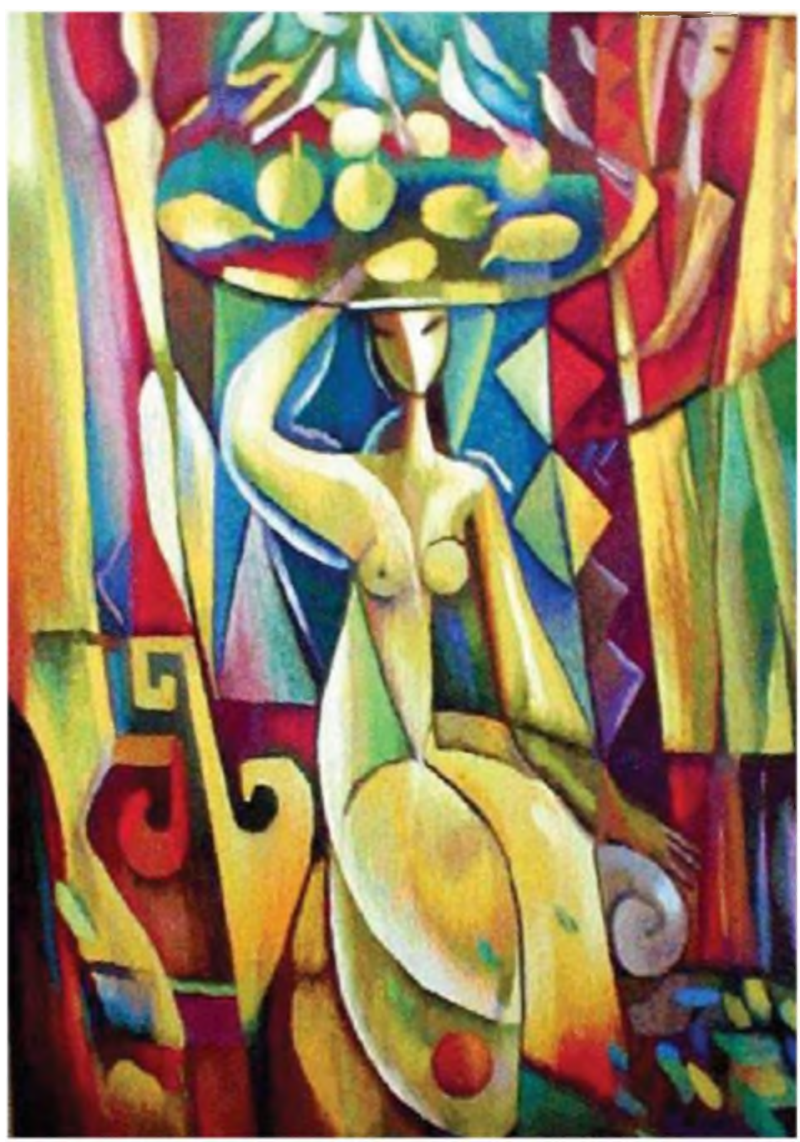

Foto 7. Kazakistan'dan Tapestry Örneği

yüzyıl tapestry örnekleri Gotik sanatının izlerini taşırken XVII. yüzyıl örnekleri Barok döneminin tipik resim anlayışından izler taşır. XX. yüzyılda ise resimde kullanılan kavramların soyutlaşması aynı dönemin tapestrylerinde de görülür.

Günümüzde tapestry dokumalar her çağda olduğu gibi geleneklere bağlı kalmaksızın çağın sanat akımına paralel bir gelişim göstermektedir. Görkemli günlerini geride bırakmış olsa da, tapestry dokumalar bugün hâlâ dokunmaktadır (Foto 7-8-9-10). Ülkemizde düzenlenen dokuma konulu konferanslarda ve sergilerde adından sıkça söz ettirmektedir. Bir duvar süsü olarak günümüzde kullanımı azalmış olsa da goblen ihtişamından hiçbir şey kaybetmemiştir.

Tapestry dokumalar dokunduğu yörenin mahalli özelliklerini yansıtmakla beraber dokunduğu yüzyıl hakkında sosyolojik, kültürel ve tarihi bilgiler vermesi açısından bir anlamda belge niteliği taşımaktadır. Bir düz dokuma türü olarak Anadolu Kilimleri Anadolu'nun tarihini bize anlatmaktadır. Dokumacılı$\breve{g} ı n$ en üst derecesini gösteren Tapestry sanatının yeni nesillere çeşitli projeler kapsamında öğretilmesi bu sanat dalının devamlılığını sağlaması açısından oldukça önemlidir. Gelecek nesillerin milli ve manevi duygularla yetiştirilmesinde bu sanatın etkisi tartışmasız bir gerçektir. Dokuma sanatını ayakta tutmak tarihe ve kültüre hizmet edeceği gibi bilinçli kuşakların yetişmesine de katkı sağlayacağını unutmamak gerekir.

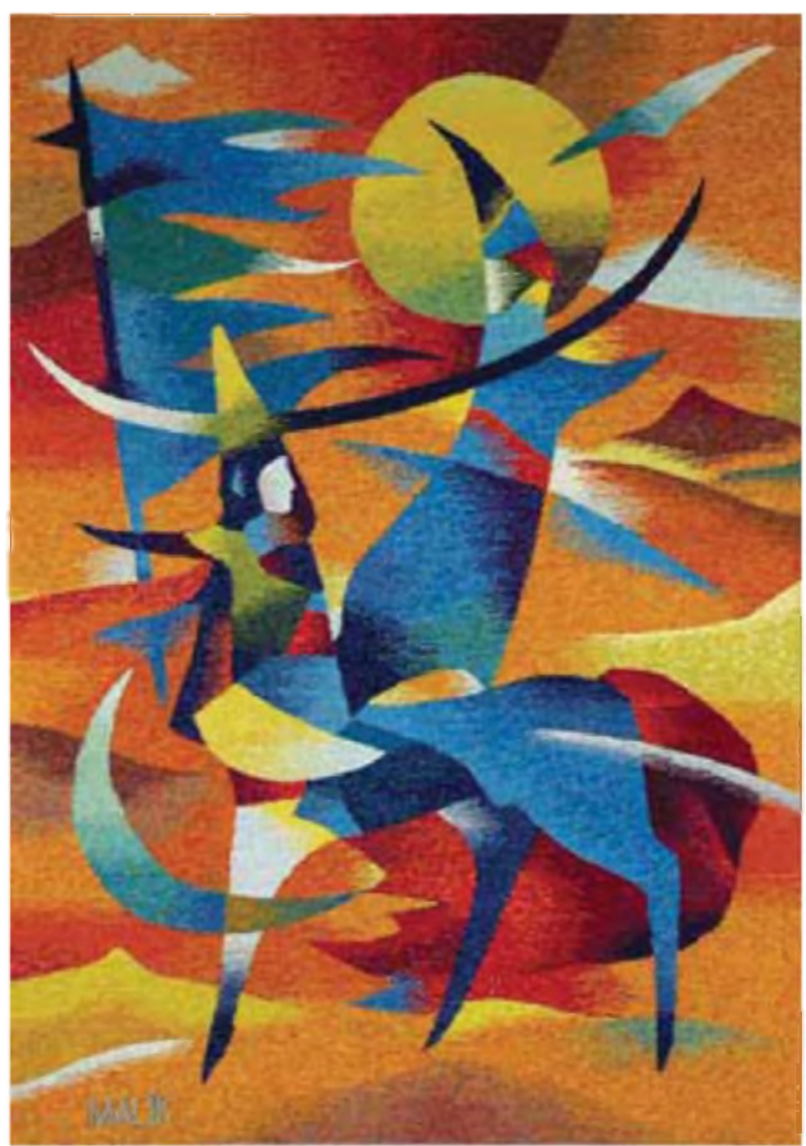

Foto 8. Kazakistan'dan Tapestry Örneği

Kaynaklar

Altın, F. (2010), Dokuma Resim (Tapestry) Sanatında Çağdaş Etkiler, Atatürk Üniversitesi Sosyal Bilimler Enstitüsü Resim Anabilim Dalı Yayımlanmamış Yüksek Lisans Tezi, Erzurum

Bolatbaev, K., Kökjiek Jane Kenistik (Kazakça), Almatı, 2008.

Ergür, A. (2002), Tekstil Terimleri Sözlüğü, İstanbul: Boğaziçi Üniversitesi Yayınevi.

Fazlıoğlu, İ. (1997), Eskiçağda Dokuma, İstanbul: Eskiçağ Bilimleri Enstitüsü Yayınları.

Grant, S. (1988), Tekstile and Art, Art and Culture Magazine, Bahar 2007, Say1: 44, s. 46. London, C., Tapestries, Milan.

Önlü, N. S. T. Arabalı Koşar (2009), "Tapestry Dokumaları nın Geleneksel Anadolu Kilimleri Ile KarşılaştırılmaS1", 10. Ulusal El Sanatlart Sempozyumu, İzmir, s.302 303.

Özay, S. (2001), Dünden Bugüne Dokuma Resim Sanati, Ankara: T.C. Kültür Bakanlığı.

Paşayeva, V.- Hamidova, Ü. (2003), "Goblen'de Kullanılan Teknik Yöntemler", Sanat, Say1 3, s. 150.

Sürür, A. (1981), "Duvar Halıcılığı", Türkiyemiz, Ekim, Sayı 35. S. 21

Sürür, A (Şubat 1982), "Goblen Dokumacıllğı", Türkiyemiz, Say1 36, s. 17.

Vipper B. (2004), Vvidenie İstoriçeskoe İzuçenie İskustva, Moskova. Zaimoğlu, Ö. (Mart 2009), "Kazak Goblen Sanatı", Yesevi, Say1 183 , s. 32-33

http://www.alfadekor.ru/index.php?Eact=61, erişim tarihi: $15 / 06 / 2010$.

http://www art-gobelen.ru/history.php, erişim tarihi: 28/06/2010.

http://www.art-gobelen.ru/history.php, erişim tarihi: 20/05/2010. 